Dedicated to the 110 anniversary of the Academician Orymbek

Akhmetbekovich Zhautykov

\author{
O.N. Stanzhytskyi ${ }^{1}$, A.T. Assanova ${ }^{2}$, M.A. Mukash ${ }^{3, *}$ \\ ${ }^{1}$ Taras Shevchenko National University of Kyiv, Kyiv, Ukraine; \\ ${ }^{2}$ Institute of Mathematics and Mathematical Modeling, Almaty, Kazakhstan; \\ ${ }^{3}$ K.Zhubanov Aktobe Regional State University, Aktobe, Kazakhstan \\ (E-mail: ostanzh@gmail.com, assanova@math.kz,mukashma1983@gmail.com)
}

\title{
Averaging method and two-sided bounded solutions on the axis of systems with impulsive effects at non-fixed times
}

\begin{abstract}
The averaging method, originally offered by Krylov and Bogolyubov for ordinary differential equations, is one of the most widespread and effective methods for the analysis of nonlinear dynamical systems. Further, the averaging method was developed and applied for investigating of various problems. Impulsive systems of differential equations supply as mathematical models of objects that, during their evolution, they are subjected to the action of short-term forces. Many researches have been devoted to non-fixed impulse problems. For these problems, the existence, stability, and other asymptotic properties of solutions were studied and boundary value problems for impulsive systems were considered. Questions of the existence of periodic and almost periodic solutions to impulsive systems also were examined. In this paper, the averaging method is used to study the existence of two-sided solutions bounding on the axis of impulse systems of differential equations with non-fixed times. It is shown that a one-sided, bounding, asymptotically stable solution to the averaged system generates a two-sided solution to the exact system. The closeness of the corresponding solutions of the exact and averaged systems both on finite and infinite time intervals is substantiated by the first and second theorems of N.N. Bogolyubov.
\end{abstract}

Keywords: small parameter, averaging method, impulsive effects, stability, equilibrium position.

\section{Introduction}

Impulsive systems of differential equations supply as mathematical models of objects that, in the course of their evolution, they are subjected to the action of short-term forces. A fairly complete theory of such systems is presented in the monograph [1]. In our article, we will use the notation and some facts from this monograph. A study of real problems with state-dependent impulsive effects can be found, for example, in [2-4].

Plenty of studies have been done on non-fixed impulsive problems. For these problems, the existence, stability, and other asymptotic properties of solutions were studied in [5, 6], and [7-9], also boundary value problems for impulsive systems were analyzed. Questions of the existence of periodic and almost periodic solutions of impulsive systems were considered in [10-12]. These problems are closely related to the existence of two-sided bounded solutions on the axis for impulsive systems. It should to said that even for systems with impulsive effects at fixed times

$$
\dot{x}(t)=X(t, x), \quad t \neq t_{i}
$$

\footnotetext{
* Corresponding author.

E-mail: mukashma1983@gmail.com
} 


$$
\left.\Delta x\right|_{t=t_{i}}=I_{i}(x)
$$

this is a rather difficult problem. The point is that, unlike ordinary differential equations, there are no theorems on the continuation of solutions to the left for impulsive systems. Indeed, the continuation of the solution to the left at the moments of impulsive effect requires global unique solvability of the nonlinear equation with impulsive effects

$$
x\left(t_{i}+0\right)=x\left(t_{i}\right)+I_{i}\left(x\left(t_{i}\right)\right)
$$

with respect to $x\left(t_{i}\right)$. It is well known that theorems on the existence of inverse mappings, in the case of a space dimension greater than 1 , are only local in nature, which their application does not permit to continue the solution to the left.

In this article, to extend solutions to the left, we have used the averaging method. This method is one of the most widespread and effective methods for the analysis of nonlinear dynamical systems. The averaging method, originally offered by Krylov and Bogolyubov for ordinary differential equations, was later developed and practiced in various problems [13-17]. The closeness of the corresponding solutions of the exact and averaged systems both on finite and infinite time intervals is substantiated by the first and second theorems of N.N. Bogolyubov.

The work consists of an introduction, a main part, where the main results and examples from mathematical biology are formulated and confirmed.

\section{The main part}

In this paper, we consider a system of differential equations with impulsive effects at non-fixed times and a small parameter of the following form

$$
\begin{gathered}
\dot{x}(t)=\varepsilon X(t, x), \quad t \neq t_{i}(x), \\
\left.\Delta x\right|_{t=t_{i}(x)}=\varepsilon I_{i}(x) \\
x(0)=x_{0}
\end{gathered}
$$

where $\varepsilon>0$ is a small parameter, $t_{i}(x)<t_{i+1}(x)(i=1,2, \ldots)$ moments of impulsive effects, functions $X$ and $I_{i} d$ are $n$ - dimensional vector of functions.

We put $U_{a}=\left\{x \in R^{d}:|x| \leq a\right\}$. Suppose the following conditions are met:

1. The functions $X(t, x)$ and $I_{i}(x)$ are continuous in the set $Q=\left\{t \geq 0, x \in U_{a}\right\}$, bounded by a constant $M>0$, and in $x$ satisfy the Lipschitz condition with a constant $L>0$;

2. Uniformly in $t, x$ for $t \geq 0, x \in U_{a}$, there exist finite limits

$$
\begin{aligned}
X_{0}(x) & =\lim _{T \rightarrow \infty} \frac{1}{T} \int_{t}^{t+T} X(s, x) d s, \\
I_{0}(x) & =\lim _{T \rightarrow \infty} \frac{1}{T} \sum_{t<t_{i}(x)<T} I_{i}(x),
\end{aligned}
$$

3. Solution $y=y(t), y(0)=x(0)$ of the averaged system

$$
\dot{y}=\varepsilon\left[X_{0}(y)+I_{0}(y)\right]
$$

is defined for $t \geq 0$ and lies in $U_{a}$ together with some neighborhood $\rho$ and is uniformly asymptotically stable;

4. The moments of the impulsive effect $t_{i}(x)$ are continuous and their functions satisfy in $U_{a}$ uniformly in $i \in N$, and the surfaces $t=t_{i}(x)$ satisfy the separation condition, that is

$$
\min _{x \in U_{a}} t_{i+1}(x)<\min _{x \in U_{a}} t_{i}(x)(i=1,2, \ldots)
$$

Suppose that there is a constant $C>0$ such that for all $t>0$ and $x \in U_{a}$

$$
i(t, x) \leq C t
$$


where $i(t, x)$ is the number of pulses on $(0, t)$.

It is also assumed that the solutions of system (1) intersect each surface $t=t_{i}(x)$ at most once, that is, there is no beating. The conditions for the absence of beating are well studied, for example, in [1, Lemmas 3.1, $3.2]$.

Theorem 1. Let Conditions 1-4 be satisfied. Then, for an arbitrary $\eta>0$, one can specify $\varepsilon_{0}$ such that $\varepsilon<\varepsilon_{0}$ for $t \geq 0$, the inequality

$$
|x(t)-y(t)|<\eta
$$

where $x(t)\left(x(0)=y(0)=x_{0}\right)$ is a solution to the exact system (1).

Proof. Solution $y=y(t)$ of the averaged system

$$
\frac{d y}{d \tau}=X_{0}(y)+I_{0}(y)
$$

$x(0)=y(0)=x_{0}$ is uniformly asymptotically stable, then for arbitrary $\eta>0$ there exists $\delta>0$ such that for any other solution $y_{1}(\tau)$ of system $(3)$ from the inequality

$$
\left|y(\tau)-y_{1}(\tau)\right|<\frac{\eta}{2} \quad \text { for } \quad \tau \geq \tau_{0},
$$

and the fulfillment of the limiting relation

$$
\lim _{\tau \rightarrow \infty}\left|y(\tau)-y_{1}(\tau)\right|=0
$$

and $\delta$ does not depend on $\tau_{0}$. In this case, we can assume that $\delta<\eta<\rho$.

Let $U_{\delta}\left(\tau_{0}\right) \delta$ denote the neighborhood of the point $y\left(\tau_{0}\right)$. By virtue of the definition of uniform asymptotically stability, limit relation (5) is uniform in $\tau_{0}$ for all neighborhoods $U_{\delta}\left(\tau_{0}\right)$. Let us show that uniformly in $x_{0} \in$ $U_{\delta}\left(\tau_{0}\right)$.

Let it not be so. Then, there are exists of a number $\mu>0$ such that $U_{\delta}\left(\tau_{0}\right)$ one can indicate a converging sequence of points $x_{n}$ and a sequence of numbers $\tau_{n}$ such that

$$
\left|x_{n}-y\left(\tau_{0}\right)\right|<\delta,\left|y\left(\tau_{n}, x_{n}\right)-y\left(\tau_{n}\right)\right| \geq \mu, \tau_{n} \rightarrow \infty
$$

where $y\left(\tau_{n}, x_{n}\right)$ is a solution to system (3) satisfying the condition $y\left(\tau_{0}, x_{n}\right)=x_{n}$. Let $\lim _{n \rightarrow \infty} x_{n}=x^{0}$. Then $\lim _{\tau \rightarrow \infty}\left|y\left(\tau, x^{0}\right)-y(\tau)\right|=0$ and we can specify $T>0$ such that the inequality

$$
\left|y\left(\tau, x^{0}\right)-y(\tau)\right|<\frac{\sigma(\mu)}{2}
$$

for all $\tau \geq T+\tau_{0}$, where $\sigma(\mu)$ is a constant guaranteeing the inclusion of solutions $y(\tau, x)$ of system (3), starting in the neighborhood $U_{\sigma(\mu)}(0)$ of the point $y(0)$, in $\frac{\mu}{2}$ - the neighborhood of the solution $y(t)$ for all $\tau \geq 0$.

Due to the continuous dependence on the initial data, it can be specified an $N>0$ such that the inequality

$$
\left|y\left(\tau, x_{n}\right)-y\left(\tau, x^{0}\right)\right|<\frac{\sigma(\mu)}{2}
$$

for all $\tau \in\left[\tau_{0}, \tau_{0}+T\right]$ and $n>N$. In this case, we can assume that $\tau_{n} \geq T+\tau_{0}$ for $n>N$. Inequalities (7) and (8) imply the inequality

$$
\left|y\left(\tau_{0}+T, x_{n}\right)-y\left(\tau_{0}+T\right)\right| \leq \sigma(\mu) .
$$

Therefore, $\left|y\left(\tau_{n}, x_{n}\right)-y\left(\tau_{n}\right)\right|<\frac{\mu}{2}$ for $\tau_{n} \geq T+\tau_{0}$, and thus, for $\tau=\tau_{n}$, the inequality $\left|y\left(\tau_{n}, x_{n}\right)-y\left(\tau_{n}\right)\right|<$ $\frac{\mu}{2}$, which contradicts one of the inequalities (6). Let us choose $T$ so that for $\tau_{n} \geq T+\tau_{0}$ the inequality $\left|y\left(\tau_{0}\right)-y_{1}\left(\tau_{0}\right)\right|<\frac{\delta}{2}$ holds if $\left|y\left(\tau_{0}\right)-y_{1}\left(\tau_{0}\right)\right|<\delta$. In view of the above, the choice of $T$ does not depend on either $\tau_{0}$ or the initial data of the solutions $y_{1}\left(\tau_{0}\right)$. According to Samoilenko's theorem [16; 113], by averaging impulsive systems, behind the indicated $\delta$ and $T$ one can find $\varepsilon_{0}$ such that for $\varepsilon<\varepsilon_{0}$ the solution $x\left(\frac{\tau}{\varepsilon}, x_{0}\right)$ of the exact system (1) is defined on the interval $[0, T]$, lies on the domain $U_{a}$ together with some neighborhood and satisfies the inequality

$$
\left|x\left(\frac{\tau}{\varepsilon}, x_{0}\right)-y\left(\tau_{0}\right)\right|<\frac{\delta}{2} \text { for } \tau \in[0, T] .
$$


Thus, the estimate required in the theorem holds on $[0, T]$, and a solution to the exact system exists on this segment.

Let us further consider the solution to the averaged system $y_{T}(\tau, \varepsilon)$ such that $y_{T}(\tau, \varepsilon)=x\left(\frac{T}{\varepsilon}, x_{0}\right)$. By virtue of estimate (9), the following estimates hold:

$$
\begin{gathered}
\left|y_{T}(\tau, \varepsilon)-y(\tau)\right|<\frac{\eta}{2} \text { for } \tau \geq T, \\
\left|y_{T}(2 T, \varepsilon)-y(2 T)\right|<\frac{\delta}{2} .
\end{gathered}
$$

Again, by virtue of the Samoilenko theorem, taking into account the uniformity in $t$ of the limit in conditions 2 , the solution $x\left(\frac{\tau}{\varepsilon}, x_{0}\right)$ of system (3) is extendable to $[T, 2 T]$, lies in $U_{a}$ together with some neighborhood, and the inequality

$$
\left|x\left(\frac{\tau}{\varepsilon}, x_{0}\right)-y_{T}(\tau, \varepsilon)\right|<\frac{\delta}{2} \text { for } \tau \in[T, 2 T] \text { and } \varepsilon<\varepsilon_{0} .
$$

From (10), (11), and the last inequality, we have the estimate

$$
\left|x\left(\frac{\tau}{\varepsilon}, x_{0}\right)-y(\tau)\right| \leq\left|x\left(\frac{\tau}{\varepsilon}, x_{0}\right)-y_{T}(\tau, \varepsilon)\right|+\left|y_{T}(\tau, \varepsilon)-y(\tau)\right|<\frac{\delta}{2}+\frac{\eta}{2}<\eta, \tau \in[T, 2 T]
$$

and for $\tau=2 T$ the estimate $\left|x\left(\frac{2 T}{\varepsilon}, x_{0}\right)-y(2 T)\right|<\delta$. Continuing this process, we obtain the validity of the statement of the theorem.

Consider the impulse system (1) and assume that now the impulses are defined on the entire axis, that is, $t_{i}(x)$ defined for $i \in Z, i= \pm 1, \pm 2, \ldots$

Theorem 2. Let the functions $X(t, x)$ and $I_{i}(x)$ be defined in the domain $Q=\left\{t \in R, x \in U_{a}\right\}\left(U_{a}=\right.$ $\left.x \in R^{d}:|x| \leq a\right)$ and in these areas

1. The functions $X(t, x)$ and $I_{i}(x)$ are continuous in terms of a set of variables, bounded by a constant $M>0$, and in $x$ satisfy the Lipschitz condition with a constant $L>0$;

2. Uniformly in $t, x$ for $t \in R, x \in U_{a}$, there exist finite limits

$$
\begin{aligned}
X_{0}(x) & =\lim _{T \rightarrow \infty} \frac{1}{T} \int_{t}^{t+T} X(s, x) d s, \\
I_{0}(x) & =\lim _{T \rightarrow \infty} \frac{1}{T} \sum_{t<t_{i}(x)<T} I_{i}(x),
\end{aligned}
$$

3. The averaged system (2) has an asymptotically stable equilibrium position $x_{0}$ in the region $U_{a}$;

4. The moments of the impulsive effect $t_{i}(x)$ are continuous functions in $U_{a}$ uniformly in $i \in N$, and the surfaces $t=t_{i}(x)$ satisfy the separation condition, that is

$$
\min _{x \in U_{a}} t_{i+1}(x)<\min _{x \in U_{a}} t_{i}(x)(i=1,2, \ldots)
$$

5. The surfaces $t=t_{-1}(x)$ and $t=t_{1}(x)$ do not intersect with the hyperplane $t=0$.

Then, for an arbitrary $\eta>0$, one can specify $\varepsilon_{0}$ such that $\varepsilon<\varepsilon_{0}$ the exact system for $t \in R$ has a solution $x(t)$ defined for $t \in R$ and the estimate

$$
\left.\mid x(t)-x_{0}\right) \mid<\eta
$$

Proof. We fix an arbitrary $\eta>0$ and construct a solution to the exact system satisfying estimate (12). Since the solution $x_{0}$ is asymptotically stable, for a given $\eta>0$ one can specify $\delta>0$ and $T>0$ such that for any solution $y(t)$ of system (2) the estimates

$$
\begin{gathered}
\left|y(\tau)-x_{0}\right|<\frac{\eta}{2} \text { for } \tau \geq \tau_{0}, \\
\left|y(\tau)-x_{0}\right|<\frac{\delta}{4} \text { for } \tau \geq \tau_{0}+T,
\end{gathered}
$$

if only $\left|y\left(\tau_{0}\right)-x_{0}\right|<\delta$, and $\delta$ and $T$ are independent of $\tau_{0}$. In this case, we can assume $\delta<\eta$. 
Let $z_{0}$ be an arbitrary point from the $\delta$-neighborhood of $x_{0}$. Consider a solution $x\left(\frac{\tau}{\varepsilon}\right)$ of the exact system that goes out at $\tau=-T$ from the point $z_{0}$. According to Samoilenko's theorem, given $\delta$ and $T$, one can choose $\varepsilon_{0}$ such that, for $\varepsilon \leq \varepsilon_{0}$, the inequality

$$
\left|x\left(\frac{\tau}{\varepsilon}\right)-y(\tau)\right|<\frac{\delta}{4} \text { for } \tau \in[-T, 0],
$$

where $y(\tau)$ is the solution to the averaged system with the condition $y(-T)=z_{0}$. From (4)-(6) it follows that $\left|x\left(\frac{\tau}{\varepsilon}\right)-x_{0}\right|<\eta, \tau \in[-T, 0]$ and $\left|x(0)-x_{0}\right|<\frac{\delta}{2}$. Therefore, for $\varepsilon<\varepsilon_{0}$, all solutions of the exact system that begin with $\tau=-T$ in the $\delta$-neighborhood of $x_{0}$, without leaving its $\eta$-neighborhood, fall, for $\tau=0$, in the $\frac{\delta}{2}$-neighborhood of this point.

By analogous reasoning, by virtue of condition 2 of this theorem, it can be shown that, for $\varepsilon<\varepsilon_{0}$, the solutions of the exact system beginning with $\tau=-n T$ in the $\delta$-neighborhood of $x_{0}$ do not leave for $\tau \in$ $[-n T,-(n-1) T]$ from its $\eta$-neighborhoods, and for $\tau=-(n-1) T$ fall into the $\frac{\delta}{2}$-neighborhood of the point $x_{0}$ for any natural $n$. We denote by $S_{n}(\varepsilon)$ the set of values of solutions of the exact system at the point $\tau=0$, which for $\tau=-n T$ lie in the $\delta$-neighborhood of the point $x_{0}$. By what was said above and the uniqueness theorem, this set is not empty for any natural number $n$ and $\varepsilon<\varepsilon_{0}$, and the inclusion $S_{n}(\varepsilon) \subseteq S_{(n-1)}(\varepsilon)$ holds. Note that by virtue of condition 5 , as follows from [1], the solutions at the point $t=0$ continuously depend on the initial data. Therefore, the sets $S_{n}(\varepsilon)$ are closed, and hence, their intersection is nonempty.

Let $z_{0}(\varepsilon)$ be a point general to all $S_{n}(\varepsilon)$. Now, for $\varepsilon<\varepsilon_{0}$, consider the solution of the exact system, which for $\tau=0$ leaves the point $z_{0}(\varepsilon)$. By its construction, at the points $-n T$, it belongs to the $\delta$-neighborhood of the point $x_{0}$ for any natural $n$. Therefore, this solution is unboundedly extendable to the left, and for any $\tau \leq 0$, estimate (12) is valid for $\varepsilon<\varepsilon_{0}$. The extendibility of the solution to the right and the validity of estimate (12) it follows from Theorem 1 . The theorem is proved.

From Theorem 3 [18; 479], it follows that under the conditions of Theorem 1, the averaged system (2) has an asymptotically stable equilibrium position. Hence, by virtue of Theorem 2 , it follows that the original impulsive system (1), defined on the entire axis, has a two-sided bounded solution on the entire axis for sufficiently small values of the parameter $\varepsilon$. Thus, the following corollary is true.

Consequence. Under conditions 1, 2, 4, 5 of Theorem 2 and condition 3 of Theorem 1, the impulse system (1) defined on the entire axis, for sufficiently small values of the parameter $\varepsilon$, has a two-sided bounded solution on the entire axis.

Thus, a one-sided, bounded, asymptotically stable solution to the averaged system (2) generates a two-sided solution to the exact impulsive system (1).

Example. Impulse model of dark reactions of photosynthesis. Consider the following impulsive system of differential equations

$$
\left\{\begin{array}{l}
\dot{x}=\varepsilon\left(x^{2}-(1+j) x y+j\right) \\
\dot{y}=\varepsilon\left(\frac{1}{7} \mu\left(7 x^{2}-y^{2}-6 x y\right), t \neq t_{i}(x, y)\right. \\
\left.\Delta x\right|_{t=t_{i}(x, y)}=f_{i}(x, y) \\
\left.\Delta y\right|_{t=t_{i}(x, y)}=g_{i}(x, y), i= \pm 1, \pm 2, \ldots
\end{array}\right.
$$

where $\varepsilon, j, \mu$ are positive parameters.

System (13) without impulsive effect at $t \geq 0$ is a well-known mathematical model of dark processes of photosynthesis in plants. There $x(t)$ is the normal concentration at time $t$ of fructose, and $y(t)$ is the normal concentration at time $t$ of glucose. This model was first suggested by D.S. Chernavsky (1967) [19], and is one of the first models that describes oscillatory processes in living nature. It turns out that at certain relationships between the parameters in this model, self-oscillation modes arise (that is, there are stable periodic solutions.

In the absence of impulses, system (13) has a unique stationary solution $x_{0}=1, y_{0}=1$. Obviously, in a neighborhood of this point, the right-hand sides of the differential part of system (13) satisfy the conditions of Theorem 2. Let also conditions 4 and 5 of this theorem with respect to impulsive effects be satisfied in this neighborhood. Suppose also that for each natural $n$ the condition

$$
\left|\sum_{-n t_{i}(x)<n} I_{i}(x, y)\right| \leq C
$$


with a constant $C$ independent of $n$. Here $I_{i}(x, y)=\left(\begin{array}{l}f_{i}(x, y) \\ g_{i}(x, y)\end{array}\right)$.

Then, obviously, condition 2 of Theorem 2 is satisfied. Moreover, $I_{i}(0)=\left(\begin{array}{l}0 \\ 0\end{array}\right)$, and therefore, the averaged system has the form

$$
\left\{\begin{array}{l}
\dot{x}=\varepsilon\left(x^{2}-(1+j) x y+j\right) \\
\dot{y}=\varepsilon\left(\frac{1}{7} \mu\left(7 x^{2}-y^{2}-6 x y\right) .\right.
\end{array}\right.
$$

Let us check the fulfillment of condition 3 of Theorem 2 for it. It is well-known [16] that for a given model, the case when the parameters of the system are related by the relation

$$
\mu=\frac{7}{8}(1-j)
$$

These are the so-called bifurcation relations, upon passing through which self-oscillation regimes arise. Therefore, we will consider this particular case. Linearizing system (14) in the vicinity of the equilibrium position $x_{0}=1, y_{0}=1$ and writing down its first approximation matrix, it is easy to see that the characteristic equation for its eigenvalues has the form

and its roots

$$
\lambda^{2}+\lambda\left(\frac{8}{7} \mu+j-1\right)+\frac{16}{7} \mu j=0
$$

$$
\lambda_{1,2}=-\frac{1}{2}\left(\frac{8}{7} \mu+j-1\right) \pm \frac{1}{2} \sqrt{\left(\frac{8}{7} \mu+j-1\right)^{2}-4 \frac{16}{7} \mu j},
$$

From biological considerations [12] it follows that $j<1$. Therefore, if $\mu>\frac{8}{7}(1-j)$, then the singular point $(1,1)$ of system $(14)$, by virtue of the stability theorem in the first approximation, is an asymptotically stable equilibrium position of system (14). Thus, condition 3 of Theorem 2 is satisfied. Consequently, for sufficiently small values of the parameter $\varepsilon$, the impulse system (13) has a solution bounded on the axis lying in a neighborhood of the point $(1,1)$. Now, let us investigate the most important case for applications (15). In this case, roots (16) will be purely imaginary and the stability theorem in the first approximation does not apply.

To study stability in this case, we use the stability index theorem (Lyapunov exponent) [17]. In this case, roots (16) have the form $\pm i \omega$, where

$$
\omega=\sqrt{2 j(1-j)}
$$

First, we find the matrix $S$ of the transition from the matrix of the first approximation system to its Jordan form

$$
\left(\begin{array}{cc}
0 & \omega \\
-\omega & 0
\end{array}\right)
$$

In our case, the matrix $S$ is found from the matrix equation

$$
S^{-1}\left(\begin{array}{cc}
1-j & -1-j \\
\frac{8}{7} \mu & -\frac{8}{7} \mu
\end{array}\right) S=\left(\begin{array}{cc}
0 & \omega \\
-\omega & 0
\end{array}\right)
$$

Now, it is made the replacement in system (14)

$$
\left(\begin{array}{l}
x \\
y
\end{array}\right)=S\left(\begin{array}{l}
z_{1} \\
z_{2}
\end{array}\right)
$$

We get the system

$$
\left\{\begin{array}{l}
\dot{z_{1}}=\varepsilon\left(z_{2} \sqrt{2 j(1-j)}+z_{1} z_{2}(1+j) \sqrt{2 j(1-j)}+z_{1}^{2} j(1+j)\right) \\
\dot{z_{2}}=\varepsilon\left(-\frac{2(1+j)}{\sqrt{2 j(1-j)}} z_{1}+\frac{1}{2} z_{1} z_{2} j(1-j)-z_{1}^{2} \frac{(1-j)\left(\frac{j^{2}}{2}+j\right)}{\sqrt{2 j(1-j)}}+z_{2}^{2} \frac{2 j(1-j)^{2}}{\sqrt{2 j(1-j)}}\right) .
\end{array}\right.
$$

Following [13], the Lyapunov rate in our case has the form 


$$
I=-\omega^{2}(1-j)\left(\frac{1}{2} j+1\right)-2 j\left(1+j^{2}\right) \omega-\frac{\omega^{3}\left(\frac{1}{2} j+1\right)}{4}+\frac{1}{8} \omega j(1-j)^{2}<0 .
$$

Therefore, according to the well-known theorem on the stability index [17], the equilibrium position $(1,1)$ of the averaged system (14) is also asymptotically stable in this case; thus, the original system (13) for sufficiently small values of the parameter e has a two-sided bounded solution on the entire axis, lying in a neighborhood of the point $(1,1)$.

\section{Acknowledgments}

This research is funded by the Science Committee of the Ministry of Education and Science of the Republic of Kazakhstan (Grant No. AP08855726).

\section{References}

1 Samoilenko A.M. Impulsive Differential equations / A.M. Samoilenko, M.O. Perestyuk. - Singapore: World Scientific, 1995. - P. 472. https://doi.org/10.1142/2892.

2 Jiao J. Analysis of a stage-structured predator-prey system with birth pulse and impulsive harvesting at different moments / J. Jiao, S. Cai, L. Chen // Nonlinear Analysis: Real World Applications. - 2011. Vol.12. - No. 4. - P. 2232-2244. https://doi.org/10.1016/j.nonrwa.2011.01.005.

3 Nie L. Dynamic analysis of an SIR epidemic model with state dependent pulse vaccination / L. Nie, Z. Teng, A. Torres // Nonlinear Analysis: Real World Applications. - 2012. - Vol.13. - No. 4. P. 1612-1629. https://doi.org/10.1016/j.nonrwa.2011.11.019.

4 Crordova-Lepe F. Stability analysis of a self-cycling fermentation model with state-dependent impulse times / F. Crordova-Lepe, R. Del Valle, G. Robledo // Math. Methods Appl. Sci. — 2014. - Vol.37. No. 4. - P. 1460-1475. https://doi.org/10.1002/mma.2907.

5 Akhmet M.U. On the general problem of stability for impulsive differential equations / M.U. Akhmet // J. Math. Anal. Appl. - 2003. - Vol.288. - No. 1. - P. 182-196. https://doi.org/10.1016/ j.jmaa.2003. 08. 001.

6 Gabor G. The existence of viable trajectories in state-dependent impulsive systems / G. Gabor // Nonl. Anal. - 2010. - Vol.72. — No. 9-10. - P. 3828-3836. https://doi.org/10.1016/j.na.2010.01.019.

7 Rachůnková I. Existence principle for higher-order nonlinear differential equations with state-dependent impulses via fixed point theorem / I. Rachůnková, J. Tomeček // Boundary Value Problems. - 2014. Vol.2014. - Art. No. 118. https://doi.org/10.1186/1687-2770-2014-118.

8 Rachunkova I. A constructive approach to boundary value problems with state-dependent impulses / I. Rachunkova, L. Rachunek, A. Ronto, M. Ronto // Appl. Math. Comp. - 2016. - Vol.274. - No. 2. P. 726-744. https://doi.org/10.1016/j.amc.2015.11.033.

9 Ronto A. Investigation of solutions of state-dependent multi-impulsive boundary value problems / A. Rontó, I. Rachůnková, M. Rontó, L. Rachůnek // Georgian Math. J. - 2017. - Vol.24. - No. 2. P. 287-312. https://doi.org/10.1515/gmj-2016-0084.

10 Samoilenko A.M. Periodic solutions of weakly nonlinear systems with impulse action / A.M. Samoilenko, N.A. Perestyuk // Differ. Equa. - 1978. - Vol.14. - No. 12. - P. 1034-1045.

11 Hakl R. Almost periodic evolution systems with impulse action at state-dependent moments / R. Hakl, M. Pinto, V. Tkachenko, S. Trofimchuk // J. Math. Anal. Appl. - 2017. - Vol.446. - No. 1. P. 1030-1045. https://doi.org/10.1016/j.jmaa.2016.09.024.

12 Dvornyk A.V. Almost periodic solutions for systems with delay and nonfixed times of impulsive actions / A.V. Dvornyk, V.I. Tkachenko // Ukr. Math. J. - 2017. - Vol.68. - No. 11. — P. 1673-1693. https://doi.org/10.1007/s11253-017-1320-z.

13 Bogolyubov N.N. Asymptotic methods in the theory of nonlinear oscillations / N.N. Bogolyubov, Yu.A. Mitropolskiy // - London: Gordon and Breach, 1961. - P. 548.

14 Zhautykov O.A. Averaging principle in nonlinear mechanics as applied to countable systems of equations / O.A. Zhautykov // Ukr. Math. J. - 1965. - Vol.17. - No. 1. - P. 39-46. 
15 Филатов А.Н. Асимптотические методы в теории дифференциальных и интегро-дифференциальных уравнений / А.Н. Филатов. - Ташкент: Фан, 1974. - 214 с.

16 Samoilenko A.M. Averaging method in systems with tremors / A.M. Samoilenko // Math. Phys. - 1971. - Vol.9. - No. 1. - P. 101-117.

17 Bruno A.D. Local methods in nonlinear differential equations / A.D. Bruno // — Berlin, Heidelberg: Springer-Verlag, 1989. - P. 348.

18 Samoilenko A.M. On the averaging of differential equations on an infinite interval / A.M. Samoilenko, A. N. Stanzhitskii // Differ. Equa. - 2006. - Vol.42. - No. 4. - P. 505-511.

19 Murray J.D. Mathematical biology / J.D. Murray // - New York: Springer-Verlag, 2001. - P. 551. https://doi.org/10.1007/b98868.

\author{
А. Станжицкий ${ }^{1}$, А. Асанова ${ }^{2}$, М. Мұқаш ${ }^{3}$ \\ ${ }^{1}$ Тарас Шевченко атындавы Киев ұлттық университеті, Киев, Украина; \\ ${ }^{2}$ Математика және математикалық модельдеу институты, Алматы, Қазақстан; \\ ${ }^{3}$ Қ. Жұбанов атындавы Ақтөөе өнірлік университеті, Ақтөөбе, Қазақстан
}

\title{
Бекітілмеген уақыт мезетіндегі импульсті жүйенің ось бойындағы екіжақты, шектелген шешімдері және орташалау әдісі
}

\begin{abstract}
Крылов пен Боголюбов жәй дифференциалдық теңдеулер үшін ұсынған орташалау әдісі сызықсыз динамикалық жүйелерді талдаудың ең танымал және тиімді әдісі болып табылады. Одан әрі орташалау әдісі әртүрлі мәселелерді зерттеуге қолданылды. Дифференциалдық теңдеулердің импульстық жүйелері өз эволюциясы барысында қысқа мерзімді күштің әсеріне ұшырайтын нысандардың математикалық модельдерін көрсетіні жақсы белгілі. Бекітілмеген импульсі бар есептерге көптеген зерттеулер арналған. Бұл есептер үшін шешімдердің бар болуы, орнықтылығы және де басқа асимптотикалық қасиеттері зерттелген және импульстік жүйелер үшін шеттік есептер қарастырылған. Оған қоса импульстік жүйелердің периодты және периодты дерлік шешімдерінің бар болуы мәселелері зерттелген. Мақалада орташалау әдісі бекітілмеген уақыт мезетіндегі дифференциалдық теңдеулер үшін импульстік жүйенің ось бойындағы екіжақты, шектелген шешімдерінің бар болуын зерттеу үшін қолданылған. Орташаланған жүйеге біржақты, шектелген асимптотикалық орнықты шешім дәл жүйеге екіжақты шешім тудыратыны көрсетілген. Дәл жүйе мен орташаланған жүйенің сәйкес шешімдерінің ақырлы да, ақырсыз да уақыт аралықтарындағы жақындығы Н.Н. Боголюбовтың бірінші және екінші теоремалары арқылы негізделген.
\end{abstract}

Kiлm сөздер: кіші параметр, орташалау әдісі, импульстік әсер, орнықтылық, тепе-теңдік күй.

\author{
А. Станжицкий ${ }^{1}$, А. Асанова ${ }^{2}$, М. Мукаш $^{3}$ \\ ${ }^{1}$ Киевский национальный университет имени Тараса Шевченко, Киев, Украина; \\ ${ }^{2}$ Институт математики и математического моделирования, Алматы, Казахстан; \\ ${ }^{3}$ Актюбинский региональный университет имени К.Жубанова, Актобе, Казахстан
}

\section{Метод усреднения и двусторонние, ограниченные на оси решения импульсных систем с нефиксированными моментами времени}

\begin{abstract}
Метод усреднения, предложенный Крыловым и Боголюбовым для обыкновенных дифференциальных уравнений, является одним из самых распространенных и эффективных методов анализа нелинейных динамических систем. Далее метод усреднения был развит и применен для исследования различных проблем. Как известно, импульсные системы дифференциальных уравнений представляют собой математические модели объектов, которые в ходе своей эволюции подвергаются действию краткосрочной силы. Задачам с нефиксированным импульсом посвящено много исследований. Для них изучены
\end{abstract}


существование, устойчивость и другие асимптотические свойства решений и рассмотрены краевые задачи для импульсных систем. Кроме того, рассматривались вопросы существования периодических и почти периодических решений импульсных систем. В статье метод усреднения использован для исследования существования двусторонних, ограниченных на оси решений импульсных систем дифференциальных уравнений с нефиксированными моментами времени. Показано, что односторонее, ограниченное, асимптотически устойчивое решение усредненной системы порождает двустороннее решение точной системы. Близость соответствующих решений точной и усредненной систем как на конечных, так и на бесконечных интервалах времени обоснована первой и второй теоремами Н.Н. Боголюбова.

Ключевые слова: малый параметр, метод усреднения, импульсное воздействие, устойчивость, положение равновесия.

\section{References}

1 Samoilenko, A.M. \& Perestyuk, M.O. (1995). Impulsive Differential equations, World Scientific, Singapore.

2 Jiao, J., Cai, S., \& Chen, L. (2011). Analysis of a stage-structured predator-prey system with birth pulse and impulsive harvesting at different moments. Nonlinear Analysis: Real World Applications, 12(4), 22322244 .

3 Nie, L., Teng, Z., \& Torres, A. (2012). Dynamic analysis of an SIR epidemic model with state dependent pulse vaccination. Nonlinear Analysis: Real World Applications, 13(4), 1612-1629.

4 Cŕordova-Lepe, F., Del Valle, R., \& Robledo, G. (2011). Stability analysis of a self-cycling fermentation model with state-dependent impulse times. Math. Methods Appl.Sci. 37(4), 2232-2244.

5 Akhmet, M.U. (2003). On the general problem of stability for impulsive differential equations. J. Math. Anal. Appl., 288(1), 182-196.

6 Gabor, G. (2010). The existence of viable trajectories in state-dependent impulsive systems. Nonl. Anal., 72 (9-10), 3828-3836.

7 Rachunkova, I., \& Tomecek, J. (2014). Existence principle for higher-order nonlinear differential equations with state-dependent impulses via fixed point theorem. Boundary Value Problems, 2014, 118.

8 Rachunkova, I., Rachunek, L., Ronto, A., \& Ronto, M. (2016). A constructive approach to boundary value problems with state-dependent impulses. Appl. Math. Comp., 274 (2), 726-744.

9 Ronto, A., Rachunkova, I., Ronto, M., \& Rachunek, L. (2017). Investigation of solutions of state-dependent multi-impulsive boundary value problems. Georgian Math. J., 24(2), 287-312.

10 Samoilenko, A.M. \& Perestyuk, N.A. (1978). Periodic solutions of weakly nonlinear systems with impulse action. Differ. Equa., 14 (12), 1034-1045.

11 Hakl, R., Pinto, M., Tkachenko, V., \& Trofimchuk, S. (2017). Almost periodic evolution systems with impulse action at state-dependent moments. J. Math. Anal. Appl., 446(1), 1030-1045.

12 Dvornyk, A.V., \& Tkachenko, V.I. (2017). Almost periodic solutions for systems with delay and nonfixed times of impulsive actions. Ukr. Math. J., 68(11), 1673-1693.

13 Bogolyubov, N.N., \& Mitropolskiy, Yu.A. (1961). Asymptotic methods in the theory of nonlinear oscillations, Gordon and Breach, London.

14 Zhautykov, O.A. (1965). Averaging principle in nonlinear mechanics as applied to countable systems of equations. Ukr. Math. J., 17(1), 39-46.

15 Filatov, A.N. (1974). Asimptoticheskie metody $v$ teorii differentsialnykh $i$ integro-differentsialnykh uravnenii [Asymptotic methods in the theory of differential and integro-differential equations]. Tashkent: Fan [in Russian].

16 Samoilenko, A.M. (1971). Averaging method in systems with tremors. Math. Phys., 9, 101-117.

17 Bruno, A.D. (1989). Local methods in nonlinear differential equations, Springer-Verlag, Berlin, Heidelberg.

18 Samoilenko, A.M., \& Stanzhitskii, A.N. (2006). On the averaging of differential equations on an infinite interval. Differ. Equa., 42(4), 505-511.

19 Murray, J.D. (2001). Mathematical biology, Springer-Verlag, New York. 